\title{
樹脂弾性体の緩衝性能に関する研究一 $\mathrm{V}$. 一船首の侵入位置と侵入角による反力一侵入量特性の変化一
}

\author{
三田重雄* ・庄司邦昭*・野々村千里**・山下勝久***
}

\section{A Study on the Shock Absorption Properties of Resin Elastic Body-V.}

\section{- About the Change of the Shock Absorption Characteristic by the Difference of Penetration Direction of the Ship-}

\author{
Shigeo MITA, Kuniaki SHOJI, \\ Chisato NONOMURA and Katsuhisa YAMASHITA
}

\begin{abstract}
During the last few years, we are doing the research that checks the characteristics of the protective device by the model experiment and numerical analysis. In the previous paper, we discussed characteristic of the time that the ship penetrated head-on at the center of protective device. These results almost agree with the numerical analyses and experiments. In the present paper, we report about the research result in the time that the ship penetrated with the protective device and change the direction, in other words, penetration position and penetration angle.

The following results are obtained.

(1) When the penetration position approaches the edge, the reaction force decreases and the slope of a reaction force-bow penetration curve becomes gradual. Also, the reaction force increases and the slope of a reaction force-bow penetration curve becomes steep, when the width of the protective device became enlarged.

(2) The reaction force-bow penetration curve in the fan shape protective device becomes the curve that has 2 strange tune points when the side of ship penetrates.

(3) Also in either condition these results almost agree with the numerical analyses and experiments.

\section{1.はじめに}

樹脂弾性体でできた緩衝工に船舶が衝突した場合 の緩衝性能を把握するため、著者らは全体が均質な 弾性体である軟質ポリウレタンフォームと、弾性樹 脂の一種である熱可塑性エラストマでできたハニカ ム構造のペルプレン緩衝工を供試体とし、模型実験 と有限要素法による数值解析により研究を進めてい る。これまでは楔形の船首が緩衝工の中央に正面か ら侵入した場合について供試体の奥行き寸法や船首

の寸法を変え、静的に侵入させた場合と衝突により 水平方向に速い速度で動的に侵入させた場合につい て検討してきた。この結果、静的な船首侵入に関し ては非線形な材料特性を有する軟質ポリウレタン フォームとペルプレン緩衝工について数值解析でも 反力ー侵入量特性を推定することが可能となり、供 試体寸法や船首寸法の影響がわかった(1)(2)(3)。また、 船首を静的に侵入させた場合と衝突により動的に侵 入させた場合とで、反力ー侵入量特性の変化に一定 の関係のあることも模型実験によってつかめた (4)。
\end{abstract}

* 正会員 東京商船大学（广135-8533 東京都江東区越中島2-1-6）

** 正会員 束洋紡績株式会社（广5520-0292 滋賀県大津市堅田2-1-1）

*** 非会員 東洋紡績株式会社（二520-0292 滋賀県大津市堅田2-1-1） 
しかしながら船舶が緩衝工の中央に直進して侵入す る場合はまれであると考之られ、針路が変わって端 部に侵入する場合や斜めに侵入する等種々の侵入状 態についてどのような影響があるか検討しておくこ とは緩衝工の設計上必要である。このようなことか ら今回は船首の侵入位置と侵入角が変化したときの 特性の変化について、軟質ポリウレタンフォームを 供試体として模型実験と数值解析により調查した。 また、従来の直方体だけでなく橋脚のコーナ一部に 適用できる扇形の緩衝工についても検討した。これ らの結果について若干の知見が得られたので以下に 報告する。

\section{2. 研究の方法}

\section{1 模型実験}

これまでの研究においては、ペルプレン緩衝工の 5 分の 1 模型(5) 想定して供試体の基本形状を幅 $0.6 \mathrm{~m} \times$ 厚み $0.2 \mathrm{~m} \times$ 奥行き $0.2 \mathrm{~m}$ の直方体とし、245 $\mathrm{kN}$ の大型万能試験機を使用して模型実験を行って きた。しかしこの寸法では侵入位置や侵入角を変化 させる場合に船首と供試体の配置を広い範囲で換え て設置する必要があり、装置類がさらに大型化して しまうため不向きである。このため今回の模型実験 では船首および供試体の大きさを従来の 2 分の 1 の 大きさとし、衝突実験装置兼用機として製作した取 扱いの容易な小型試験機を使用した。写真 1 に小型 試験機の外観を示すが、供試体への船首押し付けは インバータモータ駆動のモータシリンダ（推力0.4 $\mathrm{kN})$ で行い、反力の検出は容量 $1 \mathrm{kN}$ のロードセル 2 個を用いた。これらは交換可能であり、例之ば駆動 部に高速のエアシリンダを使うとか、容量の大きい ロードセルに換える等が可能である。また、駆動部 を取り除くと慣性を利用して低摩擦で船首を移動さ

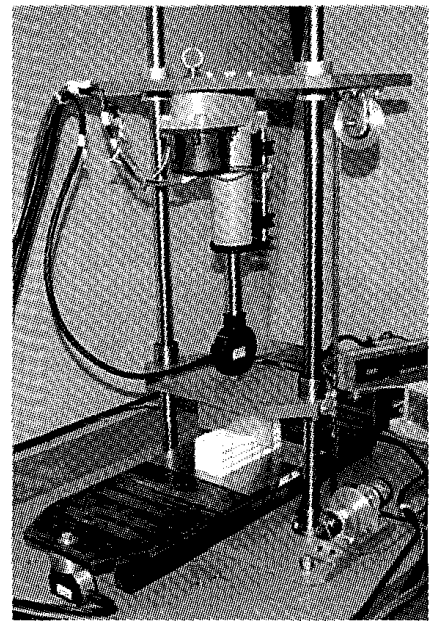

写真 1 小型試験機の外観
せることができ、衝突実験装置としても使用可能で ある。

使用した船首模型の形状は開き角 $35^{\circ}$ の楔形で、先 端半径の大きさを従来の 2 分の 1 の $5 \mathrm{~mm}$ とし、供試 体の基本形状も幅 $0.3 \mathrm{~m} \times$ 厚み $0.1 \mathrm{~m} \times$ 奥行き $0.1 \mathrm{~m}$ の直方体とした。本研究においては船首の侵入位置 と侵入角の緩衝性能への影響を幅広く検討するた め、図 1 に示すように、供試体の幅を0.1〜0.6mとし て侵入位置を変化させる、供試体幅は基本の $0.3 \mathrm{~m}$ と して侵入角と侵入位置を変化させる、供試体を取り 付け面半径 $0.2 \mathrm{~m} \times$ 奥行き $0.1 \mathrm{~m} \times$ 開き角 $90^{\circ}$ の扇形 として侵入位置を変化させる、3 種類の模型実験を 行って反力ー侵入量特性を求めた。また、扇形供試 体の実験については船首侵入だけでなく船側で押し 付けられる状態についても検討した。供試体の材料 は軟質ポリウレタンフォームで、従来と同じ見掛密 度 $45 \mathrm{~kg} / \mathrm{m}^{3}$ のもので、船首の押し付け速度も従来と 同じ $20 \mathrm{~mm} / \mathrm{min}$ とし。なお、本論においてはこれ 以降長さ寸法を “mm”単位に統一して表示すことと
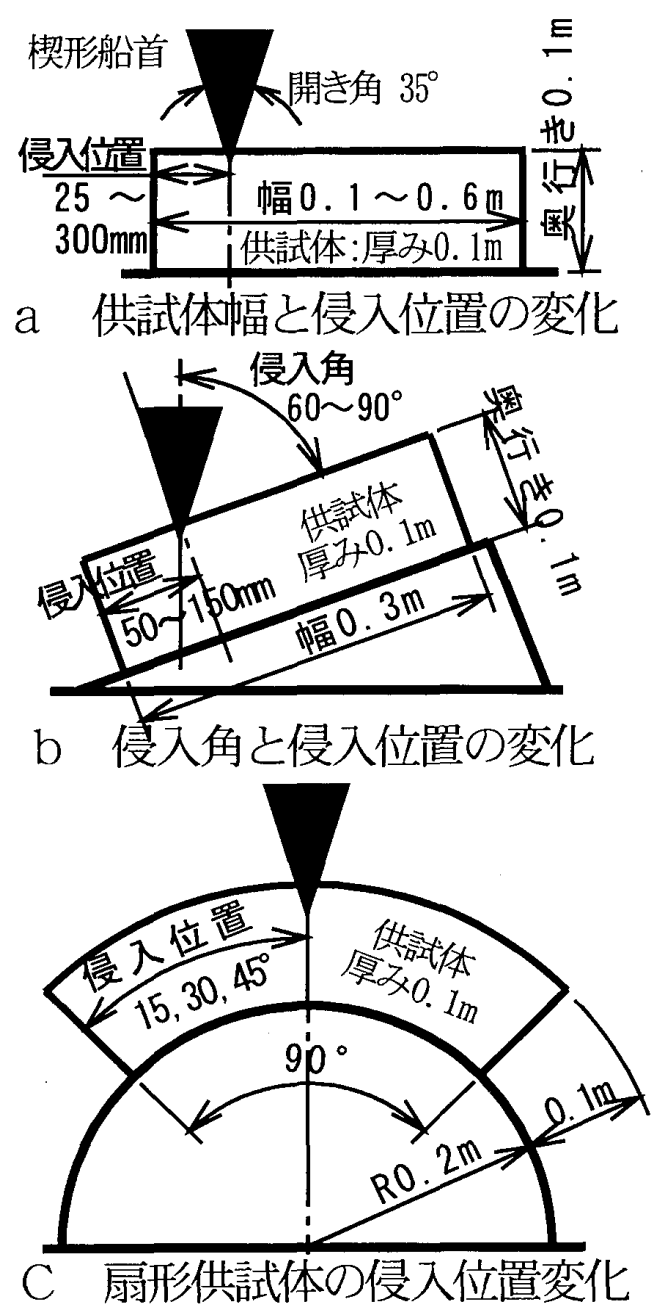

図 1 実験状態と供試体の形状 
する。

\section{2 数値解析}

数值解析は沉用有限要素法ソフトウエア (MARC K7）により、供試体の幅寸法と船首侵入位置、侵入 角等の状態を模型実験よりも範囲を広げて調查し た。数值解析のモデルは船首部分を完全剛体、緩衝 工部分を弾性体と仮定することで、緩衝工部分の変 形挙動のみを考慮した。弾性体の材料の定義方法は 大変形を伴う場合において、一般的に弾性体を取扱 う場合の構成則であったMooney-Rivlin構成則や Ogden構成則に代表される非線形弾性構成則 ${ }^{(6)}$ が利 用されているが、船首進入時の数値解析においては 緩衝工の空隙の変化があるため、体積変化を許容す るフォームモデルを適用して実際の変形挙動や反力 の予測が精度良く再現できるように考慮した。また、 形状のモデル化において、従来は船首が緩衝工の中 央に正面から侵入した場合を対象として扔り、解析 には対称性を考慮して $1 / 2$ モデルを使い、船首先端部 と供試体中央の接触部との変位を拘束した境界条件 を使用していた(7)(8)。しかし、今回は偏荷重のため従 来のモデルが使えないので解析モデルは全体モデル とし、船首と供試体との変位は拘束せずに摩擦を考 慮（摩擦係数 $\mu=0.2 ）$ した境界条件を使って数值解 析を行った。また、要素分割にも注意を払い、船首 部分のモデルでは先端のコーナ一部の外周を角度 $5^{\circ}$ 毎の直線に近似して定義し、供試体のモデルで は接触部の形状による䛊差が減少するように接触部 付近において要素の幅を細分化して定義した。なお、 幅 $300 \mathrm{~mm}$ 以下の直方体および扇形供試体では供試 体全体の変形を精度良く再現するため、モデル全体 を均等に分割した。

\section{3. 結果および考察}

\section{1 直方体形供試体の供試体幅と船首侵入位置 による反カー侵入量特性の変化}

実験装置ならびに供試体の大きさを従来と変更し たので、船首侵入実験に先立ち平板を使っての100 $\mathrm{mm}$ 角供試体の全面圧縮実験を行って圧縮特性を求 めた。その結果を図 2 に、文献(1)に示す大型試験機 による $200 \mathrm{~mm}$ 角供試体の実験値を併記して示す。圧 縮速度は両者とも同じで、 $20 \mathrm{~mm} / \mathrm{min}$ である。両者 の圧縮特性は殆ど一致しており、本試験機の試験精 度は良好で、供試体の大きさについても従来と相似 関係にあることが確認できた。

次に、図 3〜9に供試体の幅を $100 \sim 600 \mathrm{~mm}$ (数値 解析では $900 \mathrm{~mm}$ まで)とし、船首の侵入位置を $25 \mathrm{~mm}$ から供試体中央まで変化させて正面から侵入させた

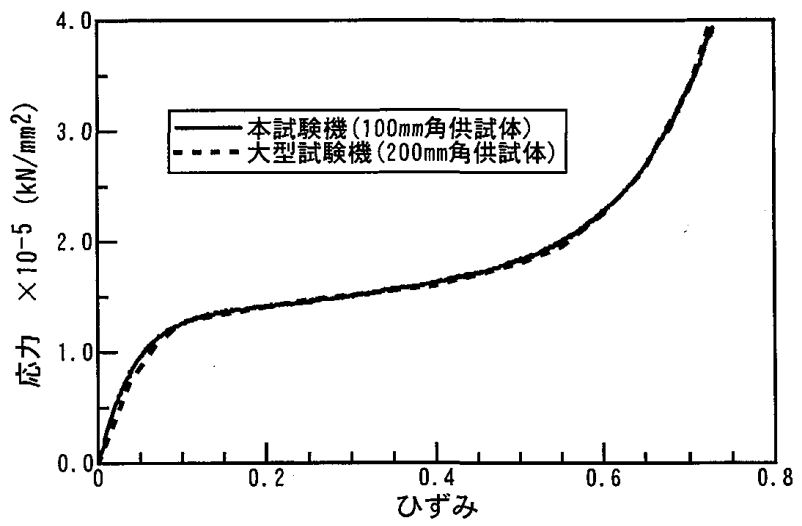

図2 圧縮特性の従来の実験值との比較

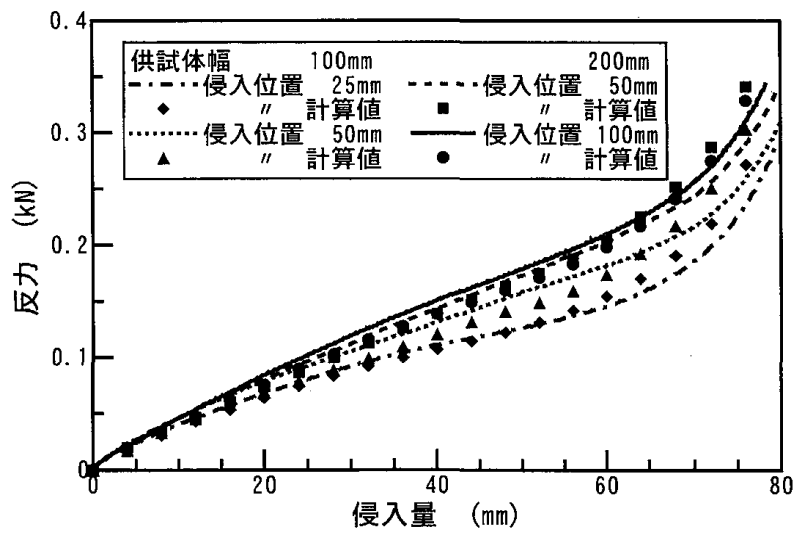

図 3 船首侵入位置による反力の変化（1）

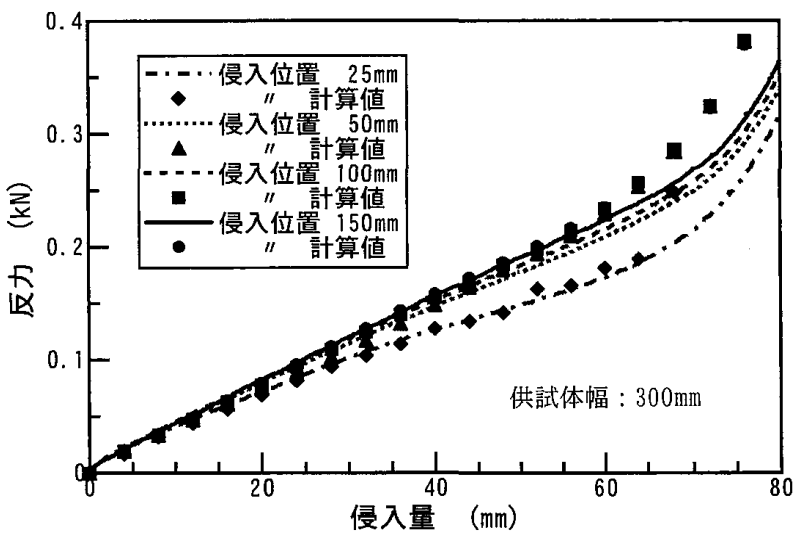

図 4 船首侵入位置による反力の変化（2）

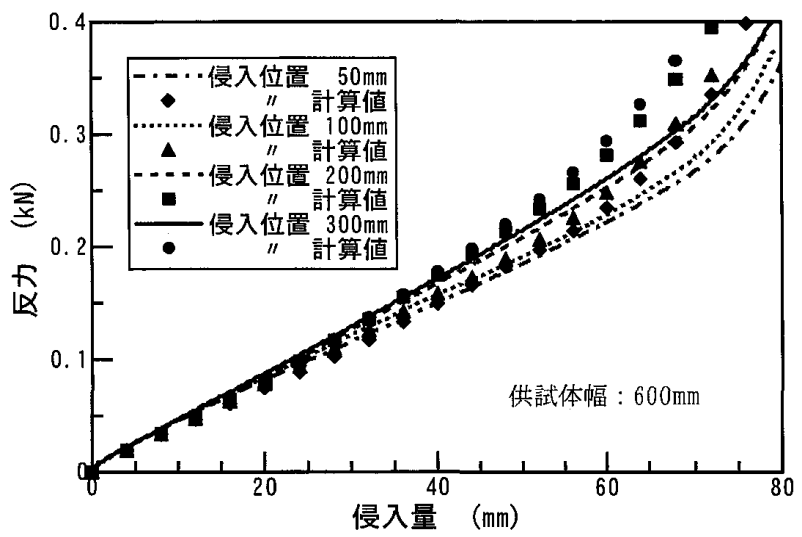

図 5 船首侵入位置による反力の変化（3） 
ときの反力ー侵入量の実験值および計算值、ならび に変形図、Uずみ分布を示す。

図 3、4、5はそれぞれ供試体幅 $100 \mathrm{~mm}$ と $200 \mathrm{~mm}$ 、 $300 \mathrm{~mm} 、 600 \mathrm{~mm}$ での反力一侵入量特性の実験值 (線 で表示）と計算值（記号で表示）を示す。困によれ ば、いずれも侵入量 $60 \mathrm{~mm}$ 位まではほぼ直線的な侵 入量に比例した反力の増加で、その後は増加割合を 增寸傾向を示しており、実験值と計算値とは侵入量 60mm位までは良く一致している。供試体の幅を同 一にした場合、侵入位置が端部に近づくと反力が減 少して勾配が小さくなり、エネルギ吸収量も減少す ることがわかる。また、大雑把に見て同じ侵入位置 でも供試体の幅が広いほど勾配が大きくなっている ことがわかる。なお侵入位置 $25 \mathrm{~mm} の$ 数值解析では、 原因は明らかではないが供試体幅 $100 \mathrm{~mm}$ 以外の侵 入量の大きいところで計算不能となった。図 6 は船 首が端部に $80 \mathrm{~mm}$ 侵入したときの供試体の変形図 を、極端な例であるが供試体幅 $100 \mathrm{~mm}$ 、侵入位置 25 mmでの模型実験と数值解析とを比較して示す。両 者は図中矢印で示す船首と供試体との接触位置や全 体的な変形状態等概ね一致している。

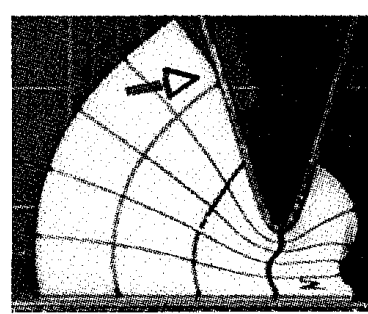

模型 実 験

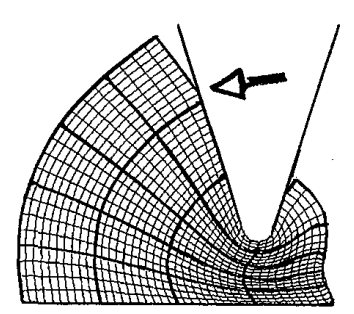

数 值 解 析
図 6 直方体での端部侵入時の変形図

以上のように実験值と計算值とはほぼ一致するこ とがわかったので、図 7 に供試体幅を100〜900 mm

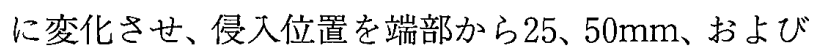
供試体中央としたときの、数值解析で求めた侵入量 20、40、60、80mmにおける反力の変化を示す。図に よれば、反力と供試体幅の関係はわずかに右上がり、 すなわち幅が広くなると反力が増加してエネルギ吸 収量も増加する傾向を示し、侵入位置 $25 \mathrm{~mm}$ と $50 \mathrm{~mm}$ とでは供試体幅 $400 \mathrm{~mm}$ 以上でほぼ平坦になり、侵入 位置が供試体中央の場合では同様に供試体幅600 $\mathrm{mm}$ 以上でほぼ平坦になっている。このことは今回 対象とした奥行き寸法 $100 \mathrm{~mm}$ の供試体では、供試体 の幅を $400 \mathrm{~mm}$ 以上に広くすれば船首の端部侵入に よる吸収エネルギの減少を最小限に抑えることがで き、さらに広げて $600 \mathrm{~mm}$ 以上にすれば中央部への侵 入も含めエネルギ吸収量をほぼ最大限にすることが

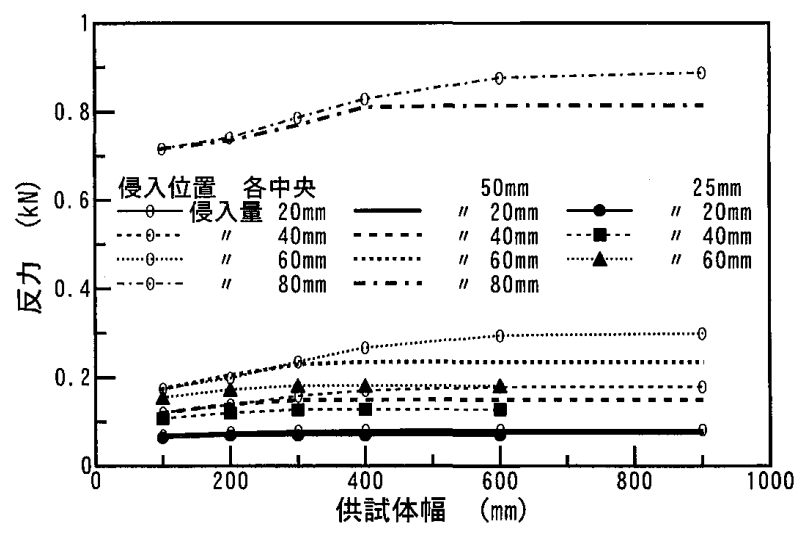

図 7 供試体幅の反力におよばす影響

できると考えられる。このような供試体幅の值は奥 行き寸法と関連するものと思われるが、今回はそこ まで解明が進んでいないので言及は避け、数值解析 法の改善も含め今後の課題と寸る。困 8 は幅300、 400、600 mmの供試体について船首が50 $\mathrm{mm}$ 侵入した ときの数值解析で求めたUずみ分布で、端部（端か ら $50 \mathrm{~mm}$ ) 侵入時と中央部侵入時について示す。図下 の “ $300 \mathrm{~mm}-50 \mathrm{~mm}-\mathrm{X}$ ” 等は先頭の $300 \mathrm{~mm}$ が供試 体の幅を、続いて侵入位置、ひずみの方向（X：供 試体の奥行き方向、Y：供試体の幅方向）を表し、 図中の数值は各方向のひずみ成分で、“+”記号が 引っ張りひずみ、“一”記号が圧縮ひずみを示す。な お、線の間隔はX方向が $0.1 、 Y$ 方向が $0.025 て ゙$ 表示 してある。供試体の幅が変化した場合に、ひずみ分 布状態には次のような変化が見られる。端部侵入で は図中の矢印で示すX方向のひずみ 0 の境界が、幅 $300 \mathrm{~mm}$ で中央を越えて侵入位置の反対側にあるの に対し、400mmでほぼ中央になり、供試体の幅が広 くなるにしたがってX方向のひずみ 0 の範囲も広 がって相対的に侵入位置側に移る。また、Y方向に 関しても同様の傾向を示す。一方、中央部に侵入し た場合 X、Y方向とも侵入位置に対して対称なひず み分布を示し、600 $\mathrm{mmでUずみ} 0$ の範囲が幅方向の 半分程度を占めるようになり、Y方向についても 300、400mmで見られる船首両脇のわずかな引っ張 りひずみの範囲が無くなって $600 \mathrm{~mm}$ では 0 の境界 線が底面に移動している。これらひずみの分布状態 は、図 7 で述べた供試体幅による反力変化の特徵の 裏づけとなるものと思われる。図 9 は実験值から求 めた吸収エネルギと侵入量の関係を、幅の異なるい くつかの供試体について侵入位置を変えて示した。 図には比較のために $100 \mathrm{~mm}$ 角供試体の平板による 全面圧縮時の值も示した。吸収エネルギは侵入量に 対して右上がりの円弧状の滑らかな曲線を示してお ク、侵入量 $30 \mathrm{~mm}$ 位までは平板圧縮の值に対してい 


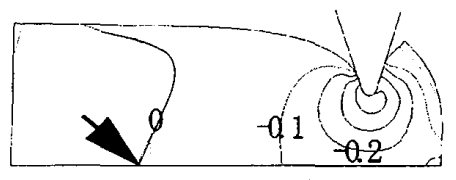

$300 \mathrm{~mm}-50 \mathrm{~mm}-\mathrm{X}$

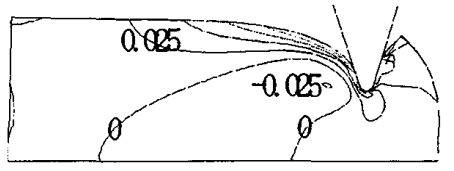

$300 \mathrm{~mm}-50 \mathrm{~mm}-\mathrm{Y}$
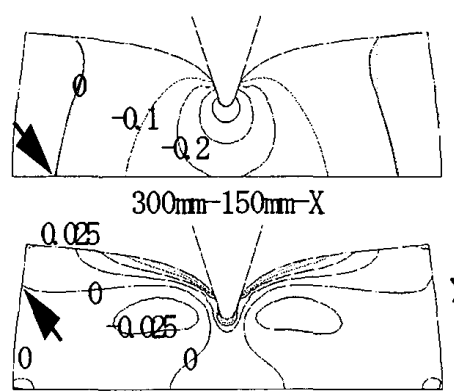

$300 \mathrm{~mm}-150 \mathrm{~mm}-\mathrm{Y}$

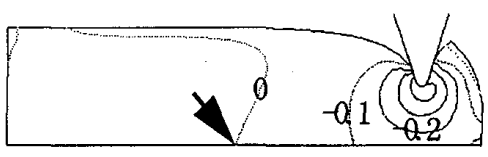

$400 \mathrm{~mm}-50 \mathrm{~mm}-\mathrm{X}$

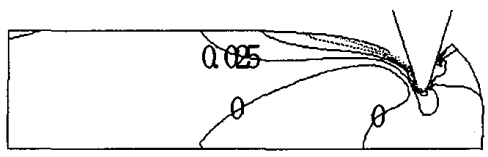

$400 \mathrm{~mm}-50 \mathrm{~mm}-\mathrm{Y}$

a 端部侵入 (侵入位置: $50 \mathrm{~mm}$ )

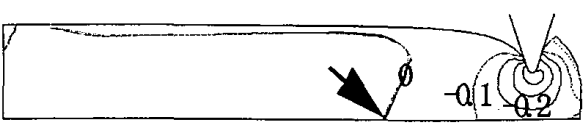

$600 \mathrm{~mm}-50 \mathrm{~mm}-\mathrm{X}$

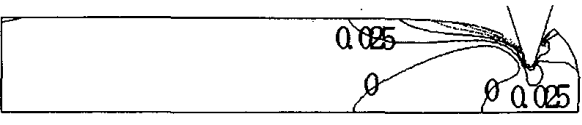

$600 \mathrm{~mm}-50 \mathrm{~mm}-\mathrm{Y}$

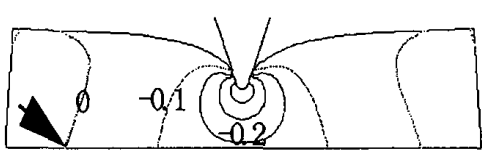

$400 \mathrm{~mm}-200 \mathrm{~mm}-\mathrm{X}$

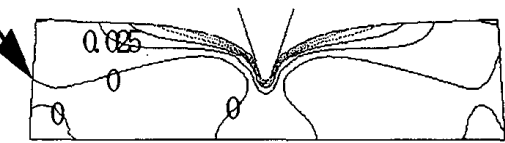

$400 \mathrm{~mm}-200 \mathrm{~mm}-\mathrm{Y}$

b 中央部侵入

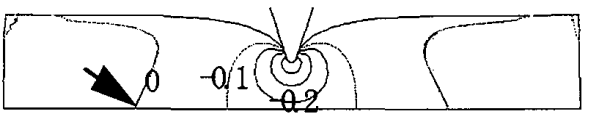

$600 \mathrm{~mm}-300 \mathrm{~mm}-\mathrm{X}$

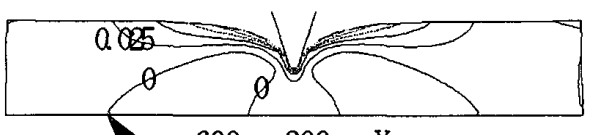

$600 \mathrm{~mm}-300 \mathrm{~mm}-\mathrm{Y}$

図 8 船首侵入位置によるUずみ分布の変化

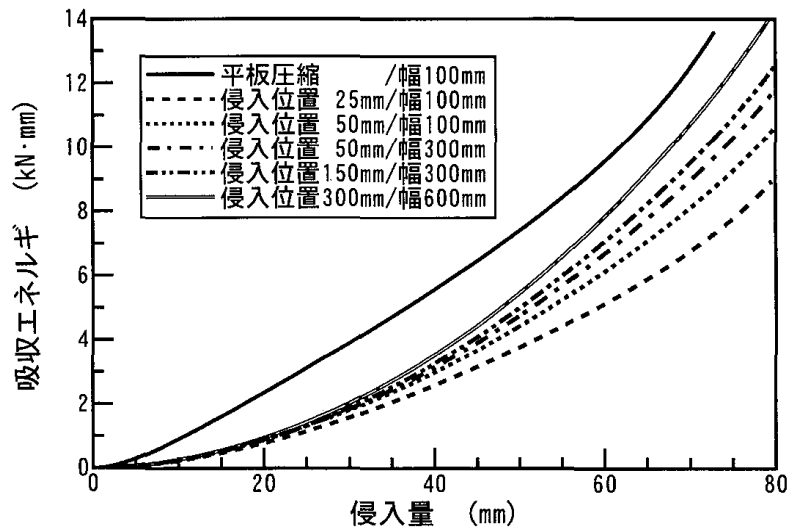

困 9 船首侵入位置による吸収エネルギの変化

ずれも50\%程度であるが、侵入量が増加して $70 \mathrm{~mm}$ に達すると65～87\%にまで達しており、前述のとお り供試体の幅が大きく侵入位置が中央に近いほどエ ネルギ吸収量も大きくなることがわかる。

図10は厚み $100 \mathrm{~mm}$ の供試体に対し、船首の当たる 範团を厚み $100 \mathrm{~mm} の$ 全範囲と $27 \mathrm{~mm}$ ずらして $73 \mathrm{~mm}$ が当たるようにした場合の反力一侵入量特性を示 す。当たる範囲を供試体の厚みよりも小さくした場 合、供試体の変形は船首の直接当たっていない 27 $\mathrm{mm}$ の部分にもおよび、反力は $100 \mathrm{~mm}$ 全範囲に均等 に侵入したときよりも $10 \%$ 程度小さいが、厚み 73 $\mathrm{mm}$ のものに均等に侵入した場合（全範囲侵入時反 力の $73 \%$ ）よりも $20 \%$ 以大きくなった。緩衝工の 高さは航行船舶の深さや潮汐・波による水面変動等 を元にして決められる(9) が、高さを多少大きめにし

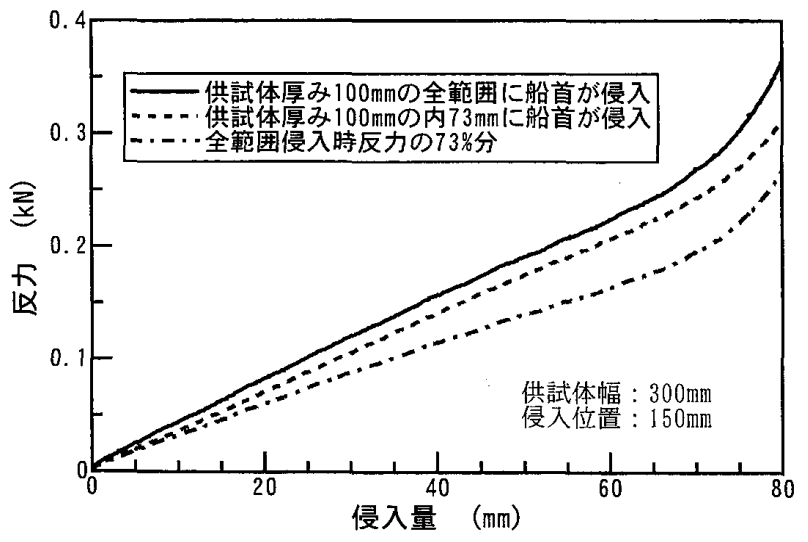

図10 厚み力向の船首侵入範囲による反力の変化

て直接接触しない範囲を設けるとエネルギ吸収量の 増加が見込める。

\section{2 侵入角と侵入位置による反カー侵入量特性 の変化}

四11～13に供試体幅を基本の300 $\mathrm{mm}$ として、侵入 角および侵入位置を変化させたときの反力一侵入量 特性を示す。なお、図中の反力、侵入量は奥行き方 向に対する值ではなく侵入方向の反力、変位量で示 してある。したがって、奥行き方向の変位量（=侵 入量 $\times \sin$ (侵入角)) は侵入角が小さいほど図中の侵 入量よりも小さくなる。また、数值解析を試みたが、 正面から侵入したときと同様に侵入量の大きいとこ ろで計算不能となったケースが多くあった。四11は 供試体の中央（侵入位置 $150 \mathrm{~mm}$ ) に侵入角 $45 \sim 90^{\circ}$ で 侵入したときの実験值（線で表示）と計算值（記号 


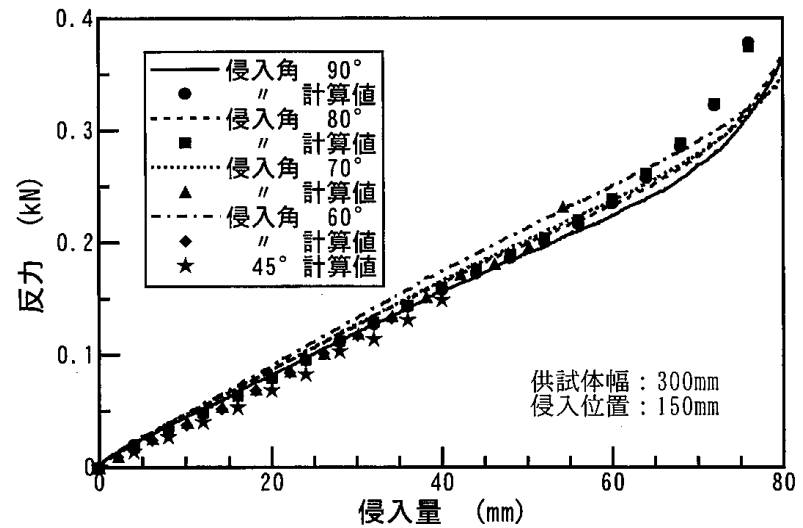

図11 中央侵入時の侵入角による反力の変化

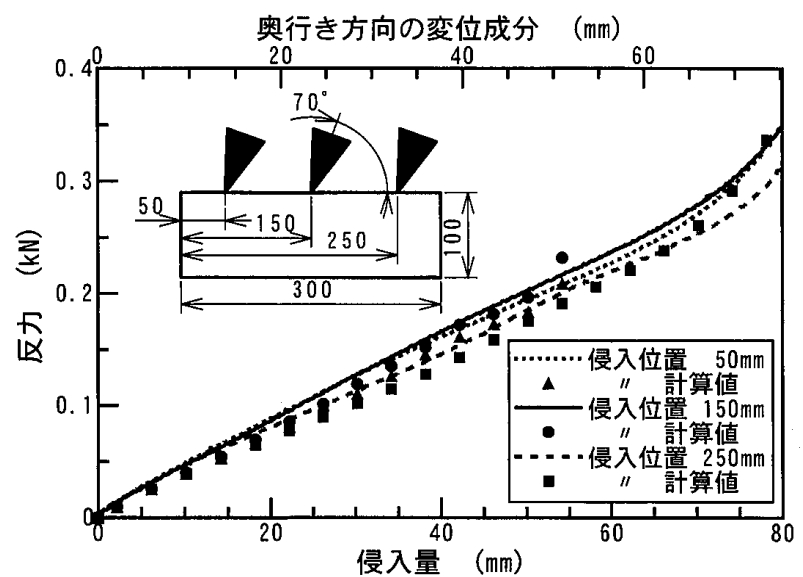

図 12 侵入角 $70^{\circ}$ での船首侵入位置による反力の変化

で表示)を示す。いずれも侵入量60～70 mm位までは 正面から侵入したときと同様にほぼ直線的な侵入量 に比例した反力の増加を示し、その後は増加割合を 増す。このような反力の全体的な変化は実験值と計 算值とでほぼ一致している。また、侵入角による反 力の変化は顕著ではないが、実験值と計算値とで異 なる傾向を示している。すなわち、侵入角が小さく なった場合に実験值では侵入量に対する反力の増加 割合が増して勾配が大きくなっているのに対し、計 算值ではごくわずかではあるが逆に減少している。

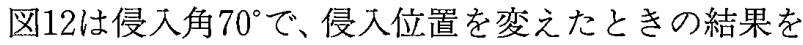
示す。侵入位置によって反力の大きさに多少の違い が現れているが、いずれも侵入量 60 ～70 mm位まで はほぼ直線的な侵入量に比例した反力の増加を示 し、その後は増加割合を増している。計算値は局部 的な変動を生じているが全体的な傾向は実験值と一 致している。侵入位置の反力におよばす影響はわず かに認められ、今回対象とした範囲では中央に侵入 したときよりも端部に侵入した方が反力は減少し、 端部を供試体の中央に向かって斜如に侵入した場合 が最も小さくなる傾向を示している。図13は図12に

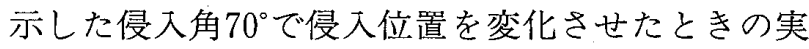

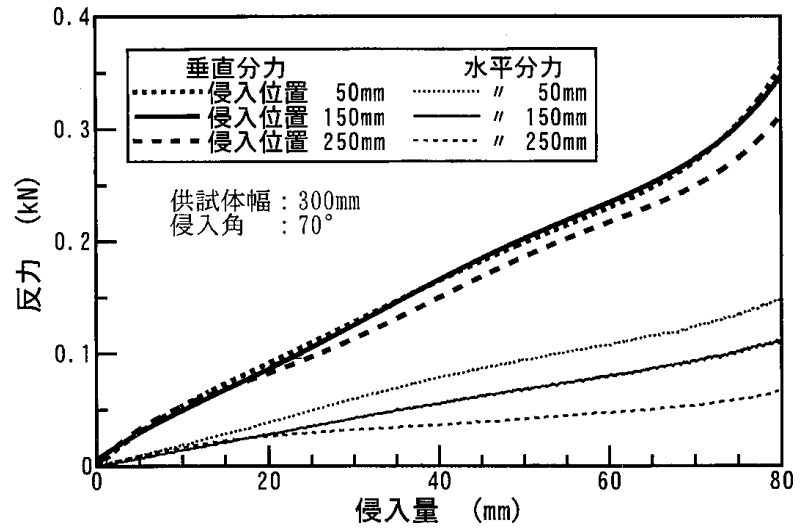

図13 斜侵入時反力の垂直 ·水平分力の比較

験值について、二分力ロードセルで計測した垂直分 力（太線で表示：奥行き方向に作用する分力）と水 平分力 (記号付細線で表示：幅方向に作用する分力) を示す。いずれも垂直分力が大半を占めており、水 平分力は垂直分力の 23 - 50\%程度になっている。ま た、垂直分力の大きさは図12に示した各侵入位置で の反力の $\sin$ 成分にほぼ等しく、水平成分では侵入位 置150mmだけが反力のcos成分にほぼ等しく、他は 前後している。これらのことから船首が緩衝工に斜 めに侵入したときでも、端部に侵入して十分に侵入 しないで緩衝工から外れるような場合を除いては正 面から侵入した場合と同程度の緩衝効果が得られる ものと思われるが、水平方向の力が作用するので緩 衝工設置に当たってはこの力も考慮する必要があ る。

\section{3 扇形供試体の反カー侵入量特性}

図14〜16に橋脚のコーナー部に設置されるような 取付け面半径 $200 \mathrm{~mm}$ 、奥行き $100 \mathrm{~mm}$ 、開き角 $90^{\circ}$ の扇 形供試体に、船首または船側が侵入位置を端部から 15 4 $45^{\circ}$ に変えて直角に侵入したときの反力一侵入 量特性の実験值および計算值、ならびに変形図を示 す。罒14は船首が侵入位置を変えて侵入した場合の

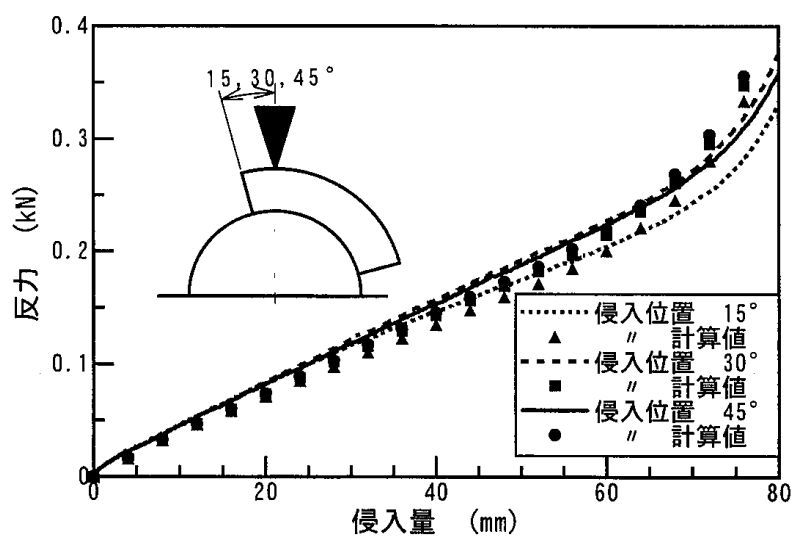

図14 扇形での船首侵入位置による反力の変化 
結果で、反力一侵入量特性の実験值（線で表示）と 計算值（記号で表示）を示す。いずれも直方体に船 首が值角に侵入したときと同様に侵入量 $60 \mathrm{~mm}$ 位ま ではほぼ直線的な侵入量に比例した反力の増加を示 し、その後は増加割合を増している。また、実験值 と計算值とは侵入量 $60 \mathrm{~mm}$ 位まではほぼ一致してお ク、いずれも侵入位置が端部に近いほどわずかでは あるが反力が減少している。罒15は図中に示すよう に扇形供試体に船首の代わりに平板を当て、船側が 侵入位置を変えて侵入した状態を模擬したときの反 力一侵入量特性で、侵入位置 $45^{\circ}$ の実験值 (線で表示) と侵入位置15、30、45 の計算值（記号で表示）を示 す。なお試験機の能力から実験では供試体の厚みを 通常の半分の $50 \mathrm{~mm}$ とし、反力は計測値を 2 倍した 值で示した。侵入位置 $45^{\circ}$ では実験值、計算值とも侵 入量 $30 \mathrm{~mm}$ と $60 \mathrm{~mm}$ 付近で変曲点を持つ右上がりの 3 次曲線状の変化を示しており、大きさも侵入量 40 $\mathrm{mm}$ 位まで良く一致している。30 の計算値も $45^{\circ}$ と同 様の傾向を示しているが、反力はわずかに減少し、 侵入途中で船側が供試体から外れるため下側の変曲

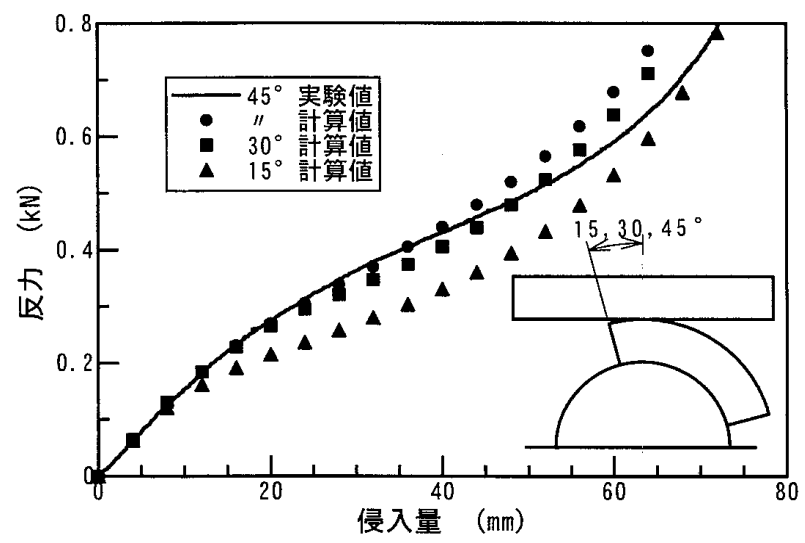

罒15 扇形での船側侵入位置による反力の変化

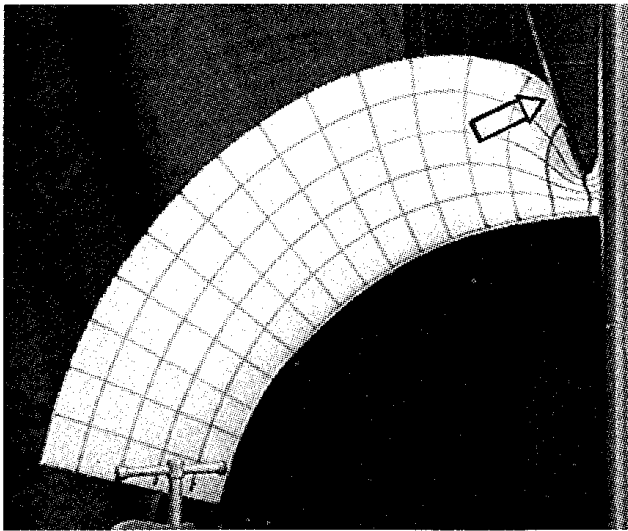

模 型 実 験
点も多少下がっている。また、15では変曲点が侵入 量 $10 \mathrm{~mm}$ 付近で現れ、反力はこれ以降さらに減少し て $45^{\circ} よ り も 25 \%$ 程度下がった值になっている。咸16 は扇形供試体に船首が端部から $15^{\circ}$ 位置に正面か ら $80 \mathrm{~mm}$ 侵入したときの変形困を模型実験と数值解 析とを比較して示す。図 6 に示した直方体の供試体 に侵入したときと同じように模型実験と数值解析と で概ね一致している。

\section{4.まとめ}

船首が侵入位置と侵入角を変之、樹脂緩衝工を想 定した軟質ポリウレタンフォーム供試体へ静的に侵 入したときの反力ー侵入量特性を模型実験と数值解 析により調查した。また供試体の形状は通常の直方 体と橋脚のコーナ一部に設置されるような扇形の 2 種類で、後者については船の側面が当たるような船 側侵入についても検討した。この結果、次のような ことがわかった。

（1）直方体の供試体に船首が侵入した場合、反力は 侵入位置と侵入角によらずひずみ 0.6 （侵入量 60 $\mathrm{mm}$ ）位まで侵入量に比例した直線的な増加を示 すが、端部に近づくほど反力が減少して勾配が小 さくなり、エネルギ吸収量が減少する。また、侵 大位置を同一にした場合は供試体の幅が大きいほ ど反力の侵入量に対する勾配は大きくなって工ネ ルギ吸収量が増加する。今回対象とした奥行き寸 法 $100 \mathrm{~mm}$ 直方体形供試体では $600 \mathrm{~mm}$ で中央部 への侵入も含めほぼ最大限になった。

（2）船首が斜めに侵入した場合、侵入角による反力 の変化は顕著ではないが、幅方向に作用する水平 分力が生じる。

（3）扇形供試体に船首が直角に侵入した場合は、反 力は直方体に侵入したときと同様に侵入量に比例
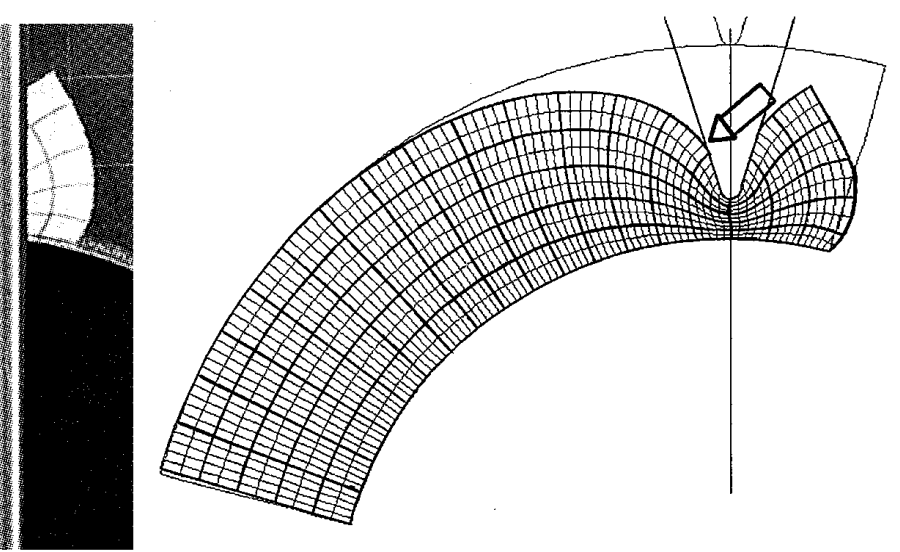

数 值 解 析

困16 扇形での船首侵入時の変形図 
した直線的な增加を示す。一方、船側が侵入する 状態では侵入位置 2 ヶ所で変曲点を持つ右上がり の 3 次曲線状の反力変化を示す。また、いずれの 場合も端部に侵入したときは中央に侵入したとき よりも反力は減少する。

また、模型実験と数値解析の結果は全てのケース でほぼ一致し、数值解析を有効に利用することがで きた。しかしながら数值解析では途中で計算のでき なくなるケースもあり、船首と供試体との接触問題 と考えられるが今後更なる実用化に向けて改善が必 要である。今回数值解析により端部侵入に対する供 試体幅の影響について細かく検討できたが、今後は、 奥行き寸法や船首寸法の影響等数値解析を有効に利 用してさらに検討を進めたい。

以上のように緩衝工が直方体でも扇形でも船首や 船側が端部に侵入すると、中央部分に侵入した場合 よりも反力が減少しエネルギ吸収量が減少すること が明らかになった。このようなことから緩衝工の設 置に当たっては、(1)できるだけ隣り合うユニットを 連結して幅を広くし、端部を少なくする。(2)やむを 得ず連結できない場合には端部を橋脚への衝突機会 の低い側に設定する。等、設置上の考慮が必要と思 われる。

本研究においては高い反発弾性を有する樹脂緩衝 工の設計資料を得ることを目的として、樹脂弾性体 に船首が静的に侵入する模型実験と数值解析ならび に衝突により動的に侵入する模型実験とを行って緩 衝性能を調查してきた。この結果、静的に侵入した 状態については本報で一般的な侵入状態についての 特性を明らかにすることができ、また、衝突時の特 性についても静的な特性との関係を文献(4)で示すこ とができた。このことから、研究の目的をほぼ達成 できたので本研究は終了とし、今後の応用研究につ いては別途報告の機会をいただきたい。

\section{参 考 文 献}

（1）三田重雄・庄司邦昭 - 野々村千里：樹脂弾性体 の緩衝性能に関する研究－I，一軟質ポリウレ タンフォームの緩衝性能一, 日本航海学会論文 集第99号，pp125-131（1998）。

（2）三田重雄・庄司邦昭・野々村千里・船城健一： 樹脂弾性体の緩衝性能に関する研究一II .一船
首の寸法による反力ー侵入量特性の変化一, 日 本航海学会論文集第100号, pp145-151(1999).

(3) 三田重雄 - 庄司邦昭 - 野及村千里 - 船城健一： 樹脂弾性体の緩衝性能に関する研究－III.—ぺ ルプレン緩衝工の反力ー侵入量特性の推定一, 日本航海学会論文集第101号, pp211218 (1999).

(4) 三田重雄・庄司邦昭・野々村千里 - 船城健一： 樹脂弾性体の緩衝性能に関する研究一IV. 一へ ルプレン緩衝工の船首衝突時の特性一, 日本航 海学会論文集第102号，pp145-151（2000）。

（5）庄司邦昭：新素材を用いた緩衝工について，日 本造船学会誌第810号，pp.10-13 (1996).

（6）久田・野口：非線形有限要素法の基礎と応用, 丸善 (1995).

（7）渡辺洋一 - 小林卓哉・船城健一 - 野々村千里 三田重雄・庄司邦昭：ポリウレタンフォーム材 の圧縮変形挙動(1)，プラスチック成型加工学会 成形加工シンポジア'98講演論文集, pp.331332 (1998).

（8）野々村千里 - 船城健一 - 小林卓哉・渡辺洋一 庄司邦昭・三田重雄：熱可塑性エラストマ一緩 衝工の船舶の衝突に対する圧縮変形挙動, 日本 機械学会第12回計算力学講演会講演論文集, pp.353-354 (1999).

（9）本州四国連絡橋公団：複合材型緩衝工の設計要 領 (案) (1981).

\section{質 疑 応 答}

間島隆博 (船舶技術研究所)：船首の侵入位置、角を 変化させたということで、より一般的な調查、研 究であり、貴重な御講演であると思います。より 実際的な問題になると思いますが、船首の破壊等 について何か御検討なされていればお教えくださ い。

三田重雄：ご質問ありがとうございます。船首の破 壊等については実験での検討はまだしていませ ん。緩衝工側の計算がうまくできるようになって きたので、今後は船首ならびに橋脚を含めた強度 についても検討する方向で進めています。数值解 析についても検討したいと考えています。 